\title{
Inhibition by oestradiol of oxidative stress-induced apoptosis in pig ovarian tissues
}

\author{
W. J. Murdoch \\ Department of Animal Science, University of Wyoming, Laramie, WY 82071, USA
}

\begin{abstract}
Oxidative stress-induced apoptotic cell death has been implicated in the mechanisms of corpus luteum regression and follicular atresia. The objective of this investigation was to determine whether the antioxidant, oestradiol influenced apoptosis in pig luteal and follicular tissues exposed in vitro to hydrogen peroxide. Immunolocalization of fragmented DNA (a biochemical marker of apoptosis) in large steroidogenic luteal and granulosa cells was inhibited by oestradiol. Protection against apoptosis required relatively high concentrations of oestradiol $\left(\geq 40 \mathrm{pg} \mathrm{ml}^{-1}\right.$ incubation media) and was largely unmitigated by actinomycin $D$ (suggesting a predominantly receptorindependent nongenomic mode of action). Ovarian cells were not protected by other (nonaromatizable) steroid hormones. It is suggested that oestradiol functions at the ovary as a reactive oxygen scavenger during pregnancy-mediated luteal rescue and folliculogenesis.
\end{abstract}

\section{Introduction}

Eutherian pregnancy is dependent upon secretion of progesterone by the corpus luteum to establish a uterine environment conducive to embryo survival (Wathes, 1992). Rescue of corpora lutea of pregnant pigs from regression is achieved by oestrogens secreted by the conceptus. Indeed, treatment of cyclic pigs with oestrogens during the period that corresponds to that of maternal recognition of pregnancy (days 11-15 after ovulation) prolongs luteal lifespan (Roberts et al., 1993). Oestrogens divert the pathway of endometrial prostaglandin (PG) $\mathrm{F}_{2 \alpha}$ release from the uterine vein toward the uterine lumen, thereby sparing corpora lutea from the luteolytic effect of $\mathrm{PGF}_{2 \alpha}$ (Bazer, 1992). Cells of corpora lutea exposed to luteolytic insults undergo oxidative damage (Behrman et al., 1993) and become committed to apoptotic death (Juengel et al., 1993; Murdoch, 1995a; Rueda et al., 1995). An ancillary (ovarian) antiluteolytic mechanism of action of oestradiol was predicted on the basis of its antioxidant capacity (Mooradian, 1993).

Oxidative stress also is a putative determinant of follicular atresia (Martimbeau and Tilly, 1997). The fact that healthy follicles exhibit a propensity toward oestrogen production could be relevant to sustained cell survival in the context of reactive oxygen downregulation. In fact, granulosa cell apoptosis is inhibited by oestrogens (Kaipia and Hsueh, 1997).

Apoptosis is a mode of programmed physiological cell death characterized by internucleosomal DNA fragmentation (Schwartzman and Cidlowski, 1993). The objective of this investigation was to determine the effects of oestradiol on in

Received 14 January 1998. situ DNA nick end-labelling in pig luteal and follicular tissues challenged in vitro with hydrogen peroxide $\left(\mathrm{H}_{2} \mathrm{O}_{2}\right)$.

\section{Materials and Methods}

Reagents were purchased from Sigma Chemical Company (St Louis, MO) unless stated otherwise.

Ovaries of cyclic Yorkshire gilts were obtained at slaughter (University of Wyoming Meat Science Abattoir). Corpora lutea (days 12-14 of the oestrous cycle) were dissected and sliced $(0.5 \mathrm{~mm}$ tissue thickness) with a Stadie-Riggs microtome. Walls of follicles more than $8 \mathrm{~mm}$ in diameter and with unclouded antral fluid were excised from the apical ovarian surface. Explants were randomized in each experiment over basal (unincubated) control and incubation groups. Incubations were carried out in $1 \mathrm{ml}$ Medium-199 (M 2154) for $2 \mathrm{~h}$ with or without steroid hormone supplements, for $30 \mathrm{~min}$ with or without $100 \mu \mathrm{mol} \mathrm{H}_{2} \mathrm{O}_{2} \mathrm{l}^{-1}$, and then for $6 \mathrm{~h}$ (without treatments) at $37^{\circ} \mathrm{C}$ in an atmosphere of $5 \% \mathrm{CO}_{2}$ and air. Steroid hormones were initially dissolved in ethanol from which stock solutions were made. The final concentration of ethanol in incubations was $0.2 \%$.

In an initial study, the effects of incubation and $\mathrm{H}_{2} \mathrm{O}_{2}$ on apoptosis were established. The prospective inhibition by oestradiol $\left(0,10,20,40,80,160\right.$ or $\left.320 \mathrm{pg} \mathrm{ml}^{-1}\right)$ of $\mathrm{H}_{2} \mathrm{O}_{2}-$ induced ovarian apoptosis was then tested. Tissues were incubated with $\mathrm{H}_{2} \mathrm{O}_{2}$ and oestradiol $\left(320 \mathrm{pg} \mathrm{ml}^{-1}\right)$, progesterone, testosterone, dihydrotestosterone or cortisol ( $320 \mathrm{pg} \mathrm{ml}^{-1}$ or $32 \mathrm{ng} \mathrm{ml}^{-1}$ ) to determine the specificity of steroid hormone action. A suppressive effect of the high dose of testosterone on follicular apoptosis was examined in the presence of the specific aromatase inhibitor 1,4,6androstatrien-3,17-dione $\left(1 \mu \mathrm{g} \mathrm{ml}^{-1}\right.$ ATD; Steraloids, Wilton, 
$\mathrm{NH}$ ). Finally, modulation of the anti-apoptotic effect of oestradiol $\left(80 \mathrm{pg} \mathrm{ml}^{-1}\right)$ by the transcriptional inhibitor actinomycin $\mathrm{D}\left(0.2 \mu \mathrm{g} \mathrm{ml}^{-1}\right)$ was assessed.

Tissues were fixed $(24 \mathrm{~h})$ by immersion in Histochoice (Amresco, Solon, OH), infiltrated with paraffin, sectioned at $5 \mu \mathrm{m}$ thickness, and transferred onto subbed microscope slides. Oncor (Gaithersburg, MD) ApopTag kits were used for single-cell detection of fragmented DNA (Murdoch, 1995a,b); this technique is more specific for apoptosis than necrosis (Allen et al., 1997). Briefly, exposed 3'-OH ends of DNA fragments were labelled with digoxigenin-11-D uridine triphosphate by terminal deoxynucleotidyl transferase (TdT) catalysis. Incorporated nucleotide heteropolymers were localized with antidigoxigenin Fab-fluorescein isothiocyanate. Conjugate or TdT were omitted in negative control reactions. Tissue sections were dehydrated and coverslips were applied. Samples within a particular experiment were processed at the same time.

Preliminary observations indicated that granulosa and large steroidogenic (granulosa lutein) cells were affected overtly by exposure to $\mathrm{H}_{2} \mathrm{O}_{2}$ and, thus, were the focus of investigation (for representative photomicrographs of immunolabelled apoptotic cells, see Murdoch, 1995a,b). Images of individual cells within three random fields per sample (Olympus BH-2 equipped with a reflected light fluorescence attachment; $\times 1000)$ were categorized using computer-assisted analysis (Optimas, Bothell, WA) as positively labelled for fragmented DNA (greater than twice the luminance intensity of control cell background) or not immunoreactive.

Subsample data were averaged. Treatment mean contrasts were made by analyses of variance and the protected least significant difference test; differences were considered significant at $P<0.05$.

\section{Results}

There were no significant differences in the (relatively low) numbers of apoptotic large luteal and granulosa cells between basal control and tissues incubated without $\mathrm{H}_{2} \mathrm{O}_{2}$. Incubation of luteal and follicular tissues with $\mathrm{H}_{2} \mathrm{O}_{2}$ caused marked consequent increases in the incidence of cells immunolabelled for fragmented DNA (Fig. 1).

Oestradiol inhibited $\mathrm{H}_{2} \mathrm{O}_{2}$-induced apoptosis among luteal and follicular cells; the response was dose dependent. Low doses of oestradiol $\left(10\right.$ and $\left.20 \mathrm{pg} \mathrm{ml}^{-1}\right)$ did not protect cells from oxidative attack, whereas higher doses provided transitional $\left(40 \mathrm{pg} \mathrm{ml}^{-1}\right)$ or complete $\left(80,160\right.$ and $\left.320 \mathrm{pg} \mathrm{ml}^{-1}\right)$ protection (Fig. 2).

Progesterone, testosterone, dihydrotestosterone or cortisol were of no comparative value in diminishing the apoptotic action of $\mathrm{H}_{2} \mathrm{O}_{2}$ toward luteal cells. Similar (negative) findings were observed with respect to granulosa cells, with the exception that the high dose of testosterone rendered some defence against apoptosis, although still significantly less defence than that conferred by oestradiol (Fig. 3). The sparing effect of $32 \mathrm{ng}$ testosterone $\mathrm{ml}^{-1}$ on granulosa cell apoptosis $(58 \pm 6 \%)$ was negated by ATD $(81 \pm 5 \%)$.

Actinomycin $\mathrm{D}$ did not alter the capacity of oestradiol to

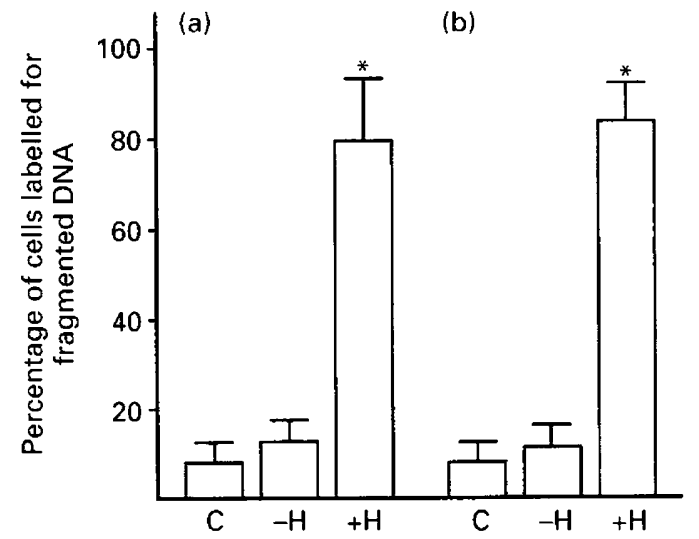

Fig. 1. Induction of apoptosis in pig (a) large luteal and (b) granulosa cells incubated with $(+\mathrm{H})$ and without $(-\mathrm{H}) \mathrm{H}_{2} \mathrm{O}_{2} . \mathrm{C}$, unincubated control. Different designations above standard error bars denote significant differences at $P<0.05(n=10)$.

prevent the luteal apoptosis elicited by $\mathrm{H}_{2} \mathrm{O}_{2}$. There was a partial proapoptotic influence of actinomycin $\mathrm{D}$ on oestradiol-treated granulosa cells (Fig. 4).

\section{Discussion}

Reactive oxygen molecules, such as $\mathrm{H}_{2} \mathrm{O}_{2^{\prime}}$ hydroxyl radicals, and superoxide anions generated during normal metabolic reactions, if not sufficiently neutralized, pose a serious threat to cell survival (Buttke and Sandstrom, 1994). The transduction pathways that link toxic oxidant accumulation to apoptosis involve peroxidative perturbations in membrane phospholipid dynamics, cytosolic calcium accretion, microskeletal disruption, DNA damage and endonuclease activation (Staler, 1984; Horton and Fairhurst, 1987; McConkey and Orrenius, 1996).

The pioneering studies of Behrman and his colleagues (1993) established a physiological role of $\mathrm{H}_{2} \mathrm{O}_{2}$ in the mechanism of luteal regression. A paradigm of oxidative stress also has been argued as a basis for ovarian follicular demise (Martimbeau and Tilly, 1997). The results of the present study indicate that oestradiol can safeguard pig luteal and follicular cells from apoptotic DNA fragmentation induced by $\mathrm{H}_{2} \mathrm{O}_{2}$; this has implications for the understanding of the processes that mediate folliculogenesis and luteal rescue during pregnancy. It appears that follicles (unlike corpora lutea) can aromatize testosterone to (bioactive) oestradiol.

A potent antioxidant action of oestrogens (that is, one that exceeds that of $\alpha$-tocopherol) has only recently been realized. The observation that oestradiol protected nerve cells from oxidative stress-induced death (Behl et al., 1995) has stimulated an interest in the potential therapeutic benefits of oestrogens in the management of dementia associated with the postmenopause and Alzheimer's disease (Henderson, 1997). Furthermore, oestradiol has been identified as an inhibitor of endothelial cell apoptosis and, thus, atherosclerosis (Spyridopoulos et al., 1997).

The minimum dose of oestradiol necessary to defend 


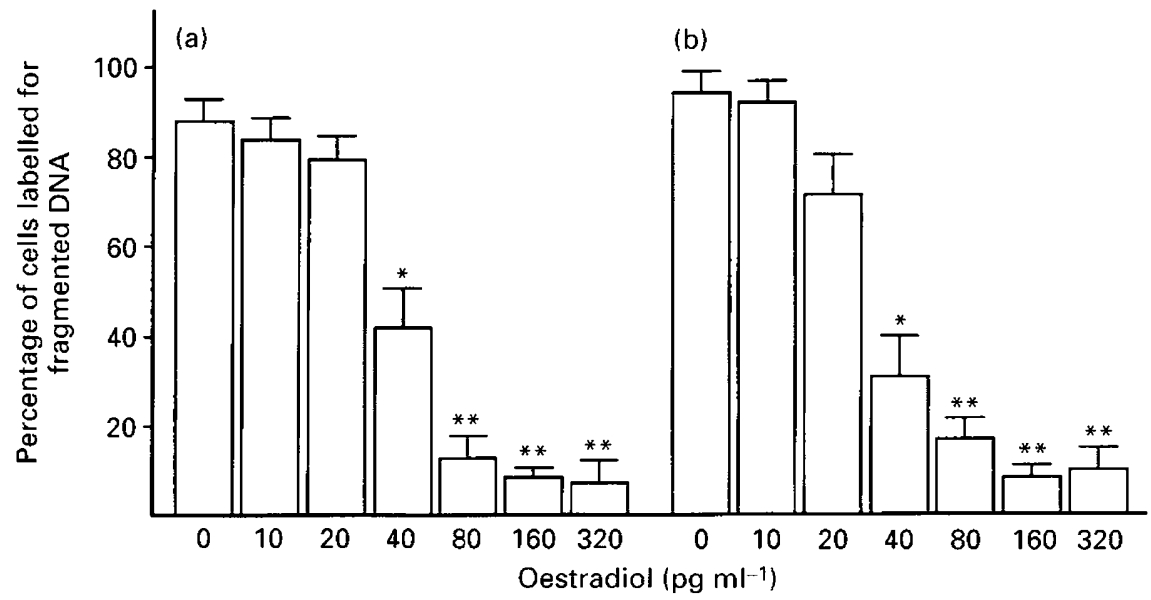

Fig. 2. Protection by oestradiol of pig (a) large luteal and (b) granulosa cells from $\mathrm{H}_{2} \mathrm{O}_{2}$ induced apoptosis. Different designations above standard error bars denote significant differences at $P<0.05(n=10)$.

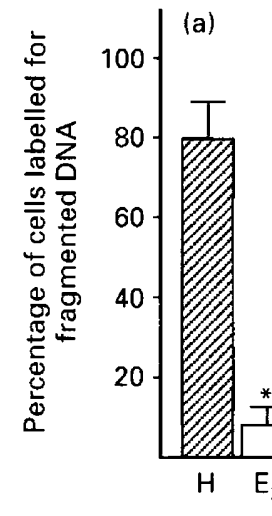

Fig. 3. Differential effects of oestradiol $\left(E_{2}\right)$, progesterone $\left(P_{4}\right)$, testosterone $(T)$, dihydrotestosterone (DHT) or cortisol (CORT) $\left(\square, 320 \mathrm{pg} \mathrm{ml}^{-1} ; \mathbf{\square}, 32 \mathrm{ng} \mathrm{m}^{-1}\right.$ ) on $\mathrm{H}_{2} \mathrm{O}_{2}(\mathrm{H})$-induced apoptosis ( $\$ ) among pig (a) large luteal and (b) granulosa cells. Different designations above standard error bars denote significant differences at $P<0.05(n=8-9)$.

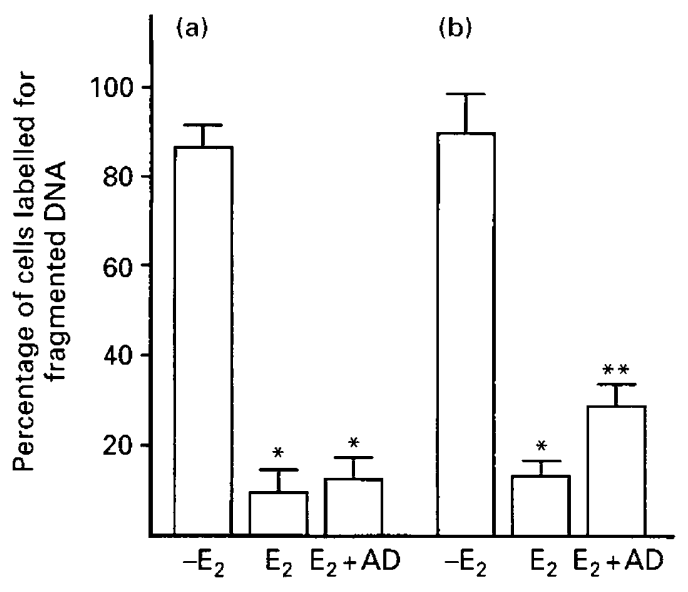

Fig. 4. Effect of actinomycin D (AD) on the antiapoptotic action of oestradiol $\left(E_{2}\right)$ in pig (a) large luteal and (b) granulosa cells. Different designations above standard error bars denote significant differences at $P<0.05(n=10)$. (b)

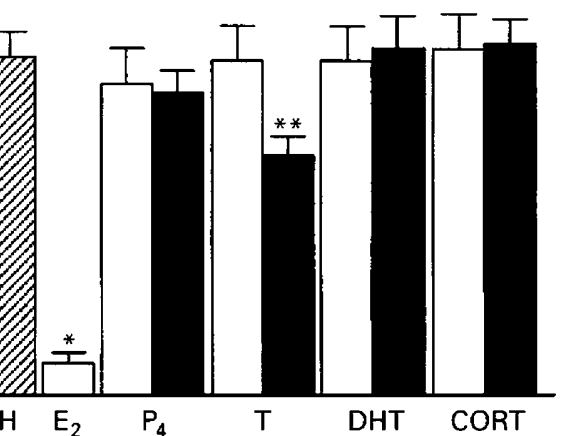


actinomycin $\mathrm{D}$ of the oestrogenic abolition of apoptosis in granulosa cells may reflect a secondary process involving the expression of DNA repair enzymes (Cristovao and Rueff, 1996; Collins et al., 1997; Murdoch and Van Kirk, 1997).

It is well known that ovarian tissues contain antioxidants (for example, $\alpha$-tocopherol, ascorbate and retinoic acid) and antioxidant enzymes (for example, superoxide dismutase, catalase and glutathione peroxidase) (Behrman et al., 1993; Kato et al., 1997). This is the first report to date that provides evidence of an ovarian antioxidant activity of oestradiol.

\section{References}

Ainsworth L, Tsang BK, Downey BR, Marcus GJ and Armstrong DT (1980) Interrelationships between follicular steroid levels, gonadotropic stimulation, and oocyte maturation during preovulatory development of porcine follicles Biology of Reproduction 23 621-627

Allen RT, Hunter WJ and Agrawal DK (1997) Morphological and biochemical characterization and analysis of apoptosis Journal of Pharmacological and Toxicological Methods 37 215-228

Anderson LL (1987) Regulation of relaxin secretion and its role in pregnancy Advances in Experimental Medicine and Biology 219 421-463

Bazer FW (1992) Mediators of maternal recognition of pregnancy in mammals Proceedings of the Society for Experimental Biology and Medicine 199 373-384

Behl C, Widmann M, Trapp T and Holsboer F (1995) 17- $\beta$ Estradiol protects neurons from oxidative stress-induced cell death in vitro. Biochemical and Biophysical Research Communications 216 473-482

Behrman HR, Endo T, Aten RF and Musicki B (1993) Corpus luteum function and regression Reproductive Medicine Reviews 2 153-180

Buttke TM and Sandstrom PA (1994) Oxidative stress as a mediator of apoptosis Immunology Today 15 7-10

Collins AR, Duthie SJ, Fillion L, Gedik CM, Vaughan N and Wood SG (1997) Oxidative DNA damage in human cells: the influence of antioxidants and DNA repair Biochemical Society Transactions 25 326-331

Cristovao L and Rueff J (1996) Effect of a poly(ADP-ribose) polymerase inhibitor on DNA breakage and cytotoxicity induced by hydrogen peroxide and $\gamma$-radiation Teratogenesis, Carcinogenesis and Mutagenesis 16 219-227

Gadsby JE, Lovdal JA, Britt JH and Fitz TA (1993) Prostaglandin $F_{2,1}$ receptor concentrations in corpora lutea of cycling, pregnant and pseudopregnant pigs Biology of Reproduction 49 604-608

Ginther Of (1974) Internal regulation of physiological processes through local venoarterial processes: a review Journal of Animal Science 39 550-564
Henderson VW (1997) The epidemiology of estrogen replacement therapy and Alzheimer's disease Neurology Supplement 748 S27-S35

Horton AA and Fairhurst S (1987) Lipid peroxidation and mechanisms of toxicity Critical Reviews in Toxicology 18 27-79

Juengel JL, Garverick HA, Johnson AL, Youngquist RS and Smith MF (1993) Apoptosis during luteal regression in cattle Endocrinology 132 249-254

Kaipia A and Hsueh AJW (1997) Regulation of ovarian follicle atresia Annual Review of Physiology 59 349-363

Kato H, Sugion S, Takiguchi S, Kashida S and Nakamura Y (1997) Roles of reactive oxygen species in the regulation of luteal function Reviews of Reproduction 281-83

Kraeling RR, Rampacek GB and Ball GD (1975) Estradiol inhibition of PGF luteolysis in the pig Journal of Animal Science Supplement 141363

Martimbeau S and Tilly JL (1997) Physiological cell death in endocrinedependent tissues: an ovarian perspective Clinical Endocrinology 46 241-254

McConkey DJ and Orrenius S (1996) Signal transduction pathways in apoptosis Stem Cells 14 619-631

Mooradian AD (1993) Antioxidant properties of steroids Journal of Steroid Biochemistry and Molecular Biology 45 509-511

Murdoch WJ (1995a) Temporal relationships between stress protein induction, progesterone withdrawal, and apoptosis in corpora lutea of ewes treated with prostaglandin $F_{2 \alpha}$ Journal of Animal Science 73 1789-1792

Murdoch WJ (1995b) Programmed cell death in preovulatory ovine follicles Biology of Reproduction 53 8-12

Murdoch WJ and Van Kirk EA (1997) Oestradiol inhibits spontaneous and cisplatin-induced apoptosis in epithelial ovarian cancer cells: relationship to DNA repair capacity Apoptosis 2478-484

Rueda BR, Wegner JA, Marion SL, Wahlen DD and Hoyer PB (1995) Internucleosomal DNA fragmentation in ovine luteal tissue associated with luteolysis: in vitro and in vivo analyses Biology of Reproduction 52 305-312

Roberts RM, Xie S and Trout WE (1993) Embryo-uterine interactions in pigs during week 2 of pregnancy Journal of Reproduction and Fertility Supplement 48 171-186

Schwartzman RA and Cidlowski JA (1993) Apoptosis: the biochemistry and molecular biology of programmed cell death Endocrine Reviews 14 133-151

Spyridopoulos I, Sullivan AB, Kearney M, Isner JM and Losordo DW (1997) Estrogen-receptor-mediated inhibition of human endothelial cell apoptosis: estradiol as a survival factor Circulation 95 1505-1514

Staler TF (1984) Free radical mechanisms in tissue injury Biochemical Journal 222 1-15

Veldhuis JD (1986) Mechanisms subserving the bipotential actions of estrogen on ovarian cells: studies with a selective anti-estrogen, LY156758, and the sparingly metabolizable estrogen agonist, moxestrol journal of Steroid Biochemistry 24 977-982

Wathes DC (1992) Embryonic mortality and the uterine environment fournal of Endocrinology 134 321-325 